\title{
Makna Puisi Kotoba (言葉) Karya Tanikawa Shuntaro: Analisis Semiotika Riffa Terre
}

\author{
${ }^{1}$ Nina Alia Ariefa \\ ${ }^{1}$ Program Studi Sastra Jepang, Fakultas Sastra, Universitas Al Azhar Indonesia, Jl. Sisingamangaraja, Jakarta
} 12110

Penulis untuk Korespondensi/E-mail:nina_alia@uai.ac.id

Abstrak - Penelitian ini bertujuan untuk untuk menemukan makna dalam puisi Kotoba karya Tanikawa Shuntaro. Teori yang digunakan dalam penelitian ini adalah semiotika dari Michael Riffaterre, yang meliputi proses pembacaan heuristik, lalu pembacaan hermeneutik berupa pencarian hipogram potensial, yang dilanjutkan dengan analisis matriks, model, dan hipogram aktual yang mengarah pada tujuan akhir penelitian ini yaitu penemuan makna pada puisi ini. Dari hasil analisis diperoleh kesimpulan bahwa tanda yang ada dalam puisi Kotoba karya Tanikawa Shuntaro memusat pada sebuah makna yaitu 'ikatan' yang terepresentasi dari kata kotoba yang bermakna 'kata'.

Kata Kunci - Puisi, Kotoba, Shuntaro Tanikawa, semiotika, Riffaterre

Abstract - This research aims to find meaning in Kotoba poetry written by Shuntaro Tanikawa. The theory used in this research is the semiotics of Michael Riffaterre, which includes the aspects of heuristic and hermeneutic reading, the analysis of potential hipogram, which is followed by the analysis of the matrix, the model, and the actual hipogram that lead to the ultimate goal of this research which is the discovery of the meaning of this poetry. The results show that the sign in this poetry focuses on a meaning which is 'bond'. This meaning is represented from kotoba word which means ' word' .

Keywords - Poetry, Kotoba, Shuntaro Tanikawa, semiotics, Riffaterre.

\section{PENDAHULUAN}

$\mathrm{B}$ ahasa sebagai penunjang aktualisasi ide, gagasan, dan tingkah laku manusia, menunjang perkembangan akal budi manusia dalam membentuk budayanya. Dilihat dari fungsinya, bahasa memiliki tiga fungsi yaitu fungsi ideasional, fungsi interpersonal, dan fungsi tekstual (Halliday: 1994). Fungsi ideasional berperan sebagai alat pengabstraksian pengalaman,. Fungsi interpersonal bahasa berkaitan erat dengan interaksi antar individu dalam kehidupan sehari-hari. Sedangkan bahasa dalam fungsi tekstual merupakan alat untuk mengkonstruksikan atau menyusun sebuah teks.
Ditinjau dari fungsi ideasional (pengabstraksi pengalaman), bahasa digunakan sebagai alat pengekspresian jiwa contohnya pada karya sastra. Bahasa pada karya sastra mempunyai sifat khusus yang berbeda, yaitu kemampuannya dalam mengungkapkan kedalaman makna dan gagasan sehingga membutuhkan penafsiran. Salah satu bentuk karya sastra yang mampu menggambarkan sifat kekhususan bahasa itu adalah puisi.

Puisi sebagai bagian dalam karya sastra pada dasarnya merupakan sarana ekspresi alam batin seseorang. Perwujudan ekspresi pengarang melalui puisi selanjutnya difasilitasi oleh bahasa yang 
bertujuan memberi kesan dan suasan emotif tertentu untuk memengaruhi perasaan atau pikiran penikmat puisi. Pradopo (2002:7) menyatakan bahwa puisi memiliki unsur-unsur berupa emosi, imajinasi, pemikiran, ide, nada, irama, kesan, panca indera, susunan kata, kata-kata kiasan, kepadatan dan perasaan pengarang semua hal tersebut terungkap dalam media bahasa.

Apresiasi puisi merupakan hasil usaha pembaca dalam mencari dan menemukan nilai hakiki puisi lewat pemahaman dan penafsiran sistematik yang dinyatakan dalam bentuk tertulis. Melalui kegiatan. Keberadaan puisi sebagai karya kreatif memungkinkan bagi sejumlah pendekatan untuk dapat dipergunakan dalam menguraikan, menafsirkan, dan bahkan menilai puisi. Salah satunya adalah melalui pendekatan yang menitikberatkan pada pembaca, atau yang disebut dengan pendekatan pragmatik.

Sebagai sarana pengungkapan ekspresi yang membentuk bangunan imajiner, puisi memuat satuan makna yang menjadi pusatnya, atau yang disebut sebagai matriks. Penemuan akan pusat makna dalam puisi Kotoba inilah yang menjadi tujuan dalam penelitian ini, dengan perumusan masalah sebagai berikut:

(1) Apa makna yang terdapat dalam puisi Kotoba karya Tanikawa Shuntaro?

\section{TELAAH TEORI SEMIOTIKA MICHAEL RIFFATERRE}

Puisi merupakan karya seni bermedia bahasa harus dipahami sebagai sistem tanda (semiotik) yang memiliki makna berdasarkan konvensi. Bahasa sebagai media puisi sudah memiliki arti sebagai bahan puisi. Oleh karena itu, bahasa disebut sebagai sistem tanda atau semiotik tingkat pertama. Makna bahasa adalah arti yang ditentukan oleh konvensi masyarakat bahasa. Dalam karya sastra, bahasa sebagai sistem tanda tingkat pertama meningkat menjadi sistem tanda tingkat kedua, yang maknanya ditentukan oleh konvensi sastra yaitu menjadi arti sastra. Arti sastra ini adalah arti dari arti (meaning of meaning) atau makna (significance). Oleh karena itu, untuk memberi makna puisi haruslah mengetahui konvensi puisi tersebut (Pradopo, 2007:279).

Di antara konvensi puisi itu adalah bahwa puisi merupakan ekspresi tidak langsung, yang dikemukakan oleh Michael Riffatere. Dalam bukunya yang berjudul Semiotics of Poetry (Riffaterre:1978), Riffaterre menganggap puisi sebagai salah satu aktivitas bahasa. Hanya saja, karena puisi berbicara mengenai sesuatu dengan maksud yang lain, berbicara secara tidak langsung, bahasa yang digunakannya pun berbeda dari bahasa sehari-hari, misalnya sebagai akibat dari adanya pengubahan (displacing) makna, penciptaan (creating) makna baru, dan perusakan (distorting) makna kebahasaan sehari-hari itu. Bahasa sehari-hari bersifat mimetik dan karenanya membangun arti (meaning) yang beraneka ragam, terpecah; bahasa puisi bersifat semiotik dan karenanya membangun makna (significance) tunggal, memusat. Sebagai ekspresi bahasa, puisi hanya dapat dipahami apabila pembacanya memahami konvensi bahasa. Akan tetapi, pembacaan atas konvensi bahasa yang disebut oleh Riffaterre sebagai pembacaan heuristik itu, tidaklah mencukupi untuk memahami makna puisi yang sesungguhnya. Dari pembacaan heuristik, pembaca harus bergerak lebih jauh ke pembacaan hermeneutik, pembacaan yang didasarkan pada konvensi sastra. Dari pemahaman makna yang masih beraneka ragam, pembaca puisi harus bergerak lebih jauh untuk memperoleh kesatuan maknanya. Gerak pembacaan lebih jauh itu dimungkinkan dan sekaligus didorong oleh adanya rintangan pada pembacaan pertama yang disebut ungramatikalitas.

Riffaterre memahami puisi sebagai sebuah donat. Apa yang hadir secara tekstual itu adalah daging donat itu, sedangkan yang tidak hadir adalah ruang kosong berbentuk bundar yang ada di tengahnya dan sekaligus menopang dan membentuk daging donat menjadi donat. Ruang kosong yang tidak ada secara tekstual tetapi yang menentukan terbentuknya puisi sebagai puisi itu disebut Riffaterre sebagai hipogram.

Hipogram dapat dibedakan menjadi dua macam, yaitu hipogram potensial dan hipogram aktual. Hipogram potensial tidak eksplisit dalam teks, tetapi dapat diabstraksikan dari teks. Hipogram potensial merupakan potensi sistem tanda pada sebuah teks sehingga makna dapat dipahami pada karya itu 
sendiri, tanpa mengacu pada teks yang sudah ada sebelumnya. Hipogram potensial itu adalah matriks yang merupakan inti dari teks atau kata kunci, yang dapat berupa kata, frase, klausa atau kalimat sederhana.

Hipogram aktual adalah teks nyata, yang dapat berupa kata, frase atau kalimat, peribahasa, atau seluruh teks, yang menjadi latar penciptaan teks baru sehingga signifikansi teks harus ditemukaan dengan mengacu pada teks lain atau teks yang sudah ada sebelumnya. Teks dalam pengertian umum hukan hanya teks teks tertulis atau teks lisan, tetapi juga adalah adat istiadat, kebudayaan, agama dan bahkan alam semesta (dunia) ini adalah teks (Pradopo 2003: 132). Oleh sebab itu, hipogram yang menjadi latar penciptaan teks baru itu bukan hanya teks tertulis atau teks lisan, tetapi juga dapat berupa adat istiadat, kebudayaan, agama, bahkan dunia ini. Hipogram tersebut direspons atau ditanggapi oleh teks baru. Tanggapan tersebut dapat berupa penerusan atau penentangan tradisi atau konvensi. Adanya tanggapan itu menunjukkan bahwa keberadaan suatu teks sastra adalah dalam rangka fungsi yang ditujukan kepada pembaca (Soeratno dalam Jabrohim 2003: 147).

Secara ringkas, hipogram potensial terkandung dalam bahasa sehari-hari seperti presuposisi dan sistem deskriptif, sedangkan hipogram aktual berupa teksteks yang sudah ada sebelumnya. Ruang kosong yang berbentuk bundar yang menopang daging donat dan membuat donat itu sebagai donat sekaligus merupakan pusat makna dari isi, pusat makna yang disebut Riffaterre sebagai matriks. Seperti halnya hipogram, matriks ini tidak ada dalam teks. Yang hadir di dalam teks adalah aktualisasinya, dan aktualisasi pertama dari matriks adalah model, yang bisa berupa makna atau kalimat tertentu. Model ini kemudian diperluas sehingga menurunkan teks secara keseluruhan. Adapun ciri utama dari model itu adalah sifat puitisnya. Model adalah sebuah tanda (kata atau kalimat) yang puitis dan sebuah tanda hanya akan menjadi puitis apabila mengacu kepada hipogram tertentu atau hipogramatik.

Kesatuan tekstual puisi yang diturunkan dari matriks dan dikembangkan dari model di atas, menurut Riffaterre, merupakan sebuah struktur yang seringkali terdiri dari satuan-satuan yang beroposisi secara berpasangan. Hubungan antar satuan itu seringkali merupakan hubungan ekuivalensi atau kesejajaran makna.

\section{METODE PENELITIAN}

Penelitian ini merupakan penelitian dengan metode deskriptif analisis. Alur kerja penelitian ini meliputi pemerolehan corpus penelitian berupa puisi yang berjudul Kotoba karya Tanikawa Shuntaro dan data kajian teoretis semiotika dari Michael Riffaterre. Langkah penelitian selanjutnya adalah proses pembacaan heuristik pada puisi, lalu pembacaan hermeneutik berupa pencarian hipogram potensial. Langkah berikutnya adalah analisis matriks, model, dan hipogram aktual yang mengarah pada tujuan akhir penelitian ini yaitu penemuan makna pada puisi Kotoba.

\section{ANALISIS MAKNA PADA PUISI KOTOBA}

Sesuai dengan metode penelitian yang telah dipaparkan pada bab tiga, analisis akan dimulai dengan pembacaan heuristik terhadap puisi Kotoba, kemudian dilanjutkan dengan pembacaan hermeneutik yaitu analisis hipogram potensial, lalu pencarian matriks, model dan hipogram aktual yang mengarah pada kesimpulan yaitu berupa penemuan makna. Berikut ini adalah hasil pembacaan heuristik pada puisi Kotoba karya Tanikawa Shuntaro.

\section{Pembacaan Heuristik}

Sebagaimana yang telah dipaparkan pada Bab 2, pembacaan heuristik adalah pembacaan yang didasarkan pada konvensi bahasa yang karenanya bersifat mimetik dan membangun serangkaian arti yang heterogen. Berikut ini adalah corpus pada penelitian ini berupa puisi yang berjudul Kotoba karya Tanikawa Shuntaro.

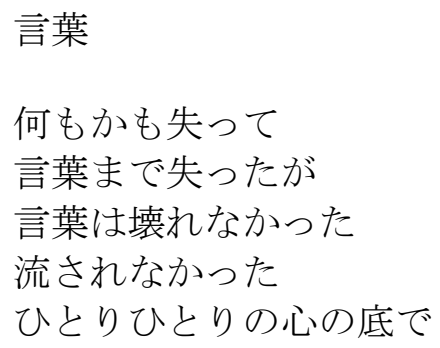




\section{言葉は発芽する \\ 瓦礫の下の大地から \\ 昔ながらの訛り \\ 走り書きの文字 \\ 途切れがちな意味 \\ 言い古された言葉が \\ 苦しみゆえに赤る \\ 哀しいゆえに深まる \\ 新たな意味へと \\ 沈黙に裏打ちされて}

Pembahasan pada bagian pembacaan heuristik akan dilakukan per bait.

Bait 1.

何もかも失って

(Nanimo kamo ushinatte)

言葉まで失ったが

(Kotoba made ushinattaga)

言葉は壊れなかった

(Kotoba wa kowarenakatta)

流されなかった

(Nagasarenakatta)

ひとりひとりの心の底で

(Hitorihitori no kokoro no soko de)

Baris pertama adalah nanimo kamo ushinatte. 'Segalanya hilang'. Pada baris ini, nanimokamo bermakna 'segala-galanya'; 'segalanya'; 'segala sesuatu'; 'semuanya'. Sedangkan ushinatte berasal dari kata ushinau yang bermakna 'kehilangan', sehingga makna dari baris pertama adalah 'segalanya hilang'. Bentuk te setidaknya memiliki dua fungsi, namun bentuk te pada kata ushinatte cenderung menyatakan sesuatu yang lain berupa penambahan penjelasan lainnya. Melalui baris pertama ini, seolaholah tergambar tentang seseorang yang sedang menyampaikan isi hatinya tentang suatu keadaan kehilangan yang entah menimpa dirinya atau menimpa orang lain.

Baris berikutnya adalah kotoba made ushinatta ga. 'Hingga kata (pun) telah hilang, tetapi'. Kotoba bermakna 'kata-kata', sedangkan made berarti 'sampai' yang setidaknya memiliki tujuh arti. Dalam konteks baris ini, kata tersebut cenderung berarti 'hingga' yang menyatakan batas suatu cakupan, yang dalam hal ini adalah kotoba, sehingga dengan demikian berarti 'hingga kata'. Dilanjutkan dengan kata ushinatta yang berasal dari kata ushinau yang bermakna 'lenyap' atau 'hilang' yang berbentuk lampau, sehingga maknanya menjadi 'telah lenyap'. Baris ini berkaitan secara langsung dengan baris sebelumnya, sehingga 'segalanya telah hilang, (bahkan) hingga kata (pun) telah lenyap. Terdapat partikel ga di akhir kata ushinatta yang dalam bahasa Indonesia dapat dipadankan dengan kata 'tetapi', yang berfungsi untuk mengungkapkan penyangkalan, atau kontradiksi antara kata/kalimat yang dipaparkan sebelum partikel 'ga' dengan kata/kalimat yang muncul sesudahnya. Hal ini berkaitan dengan baris ketiga yaitu kotoba wa kowarenakatta. 'Kata-kata tidak rusak'. Kotoba berarti 'kata'. Kotoba diikuti oleh partikel $w a$. Partikel $w a$ tidak memiliki padanan kata dalam bahasa Indonesia. Partikel tersebut berfungsi sebagai penanda bahwa kata sebelumnya (yaitu kotoba) menjadi topik atau sesuatu yang ditekankan. Kowarenakatta berasal dari kata kowareru (yang bermakna 'rusak' atau 'hancur'), yang dalam bentuk negatif berubah menjadi kowarenai yang bermakna 'tidak rusak'. Bentuk ta pada kowarenakatta yang berasal dari bentuk kowarenai merupakan penanda bentuk lampau, yang menunjukkan bahwa keadaan 'tidak rusak/hancur' tersebut telah terjadi pada masa lampau. Bila dihubungkan dengan baris sebelumnya, maka '(bahkan) hingga kata (pun) telah lenyap, tetapi kata tidak rusak'.

Baris berikutnya adalah nagasarenakatta. 'Tidak hanyut'. Baris ini berkaitan dengan baris sebelumnya karena masih membicarakan tentang topik yang sama, yaitu kotoba 'kata'. Nagasarenakatta berasal dari kata nagasu yang bermakna 'mengalirkan' atau 'menghanyutkan'. Kata nagasareru merupakan kata nagasu dalam bentuk pasif, sehingga bermakna 'dialirkan' atau 'dihanyutkan'. Bentuk pasif yang digunakan pada kata nagasu, menyatakan bahwa sesuatu itu, yang dalam hal ini (mengacu pada baris sebelumnya) adalah 'kata', telah dihanyutnya oleh sesuatu yang belum diketahui dengan jelas hingga baris ini, namun terdapat indikasi bahwa penyebabnya memiliki kemampuan untuk mengalir dengan deras sehingga dapat menghanyutkan sesuatu. 
Nagasarenakatta adalah kata nagasareru dalam bentuk negatif (nagasarenai). Bentuk ta di akhir kata nagasarenakatta menunjukkan bentuk lampau, yang berarti sesuatu yang 'tidak hanyut' tersebut telah terjadi di masa lalu. Dengan demikian, bila dikaitkan dengan dua baris sebelumnya menjadi '(bahkan) hingga kata (pun) telah lenyap, tetapi kata tidak rusak, tidak dihanyutkan'.

Baris berikutnya adalah 'Di lubuk hati masingmasing orang'. Hitori hitori no kokoro no soko de. Kata hitori sendiri bermakna 'satu orang' atau 'seorang'. Kata hitori-hitori bermakna 'setiap orang' atau 'masing-masing orang'. Kata kokoro bermakna 'hati' atau 'perasaan' yang mengacu pada kata hitorihitori. Terdapat partikel no yang berada di antara kedua kata tersebut yang berfungsi untuk saling menjelaskan, sehingga makna hitori-hitori no kokoro adalah 'hati masing-masing orang'. Soko berarti 'dasar'. Bila dihubungkan dengan frase sebelumnya yaitu hitorihitori no kokoro, maknanya menjadi 'dasar/lubuk hati masing-masing orang'. Partikel de yang terdapat pada akhir baris ini memiliki beberapa fungsi, namun dalam konteks baris ini berfungsi untuk menunjukkan letak atau posisi, yang dalam bahasa Indonesia, padanannya adalah kata di. Dengan demikian, baris ini bermakna 'di lubuk/dasar hati masing-masing orang'. Subyek/topik pada baris ini dilesapkan, namun setidaknya baris ini koherensinya dapat terjelaskan bila kita pertalikan dengan barisbaris sebelumnya, yaitu pada baris ketiga yaitu kotoba, 'kata', sehingga yang tetap berada di lubuk hati masing-masing orang adalah 'kata'.

Bait 2.

言葉は発芽する

(Kotoba wa hatsuga suru)

瓦礫の下の大地力ら

(Gareki no shita no daichi kara)

昔ながらの訛り

(Mukashi nagara no namari)

走り書きの文字

(Hashirigaki no moji)

途切れがちな意味

(Togiregachina imi)

Baris pertama pada bait kedua adalah kotoba wa hatsuga suru. 'Kata mulai tumbuh (bertunas)'.
Kotoba bermakna 'kata', sedangkan hatsuga suru berarti 'bertunas/bersemi/berkecambah'. 'Bertunas' berarti tumbuhan muda yang baru timbul atau yang baru mulai tumbuh. Partikel $w a$ kembali menandai kotoba pada baris ini, sehingga kotoba 'kata' menjadi topik. Selain itu bentuk kamus yang digunakan pada hatsuga suru menandakan bahwa aktivitas 'tumbuh/bertunas' akan terjadi di masa depan. Dengan demikian baris ini berarti 'kata akan tumbuh/bertunas'. Dari konvensi bahasa, koherensi baris ini dengan bait sebelumnya terdapat pada adanya perulangan 'kata' yang dijadikan sebagai topik, sehingga situasi imajiner yang terbangun antara bait pertama dengan baris pertama pada bait kedua ini adalah pergerakan mengenai kisah 'kata' yang menyusuri dimensi waktu dari masa lalu menuju masa depan. Di masa lalu 'kata' telah 'lenyap'. Namun meskipun 'lenyap', 'kata tidak rusak dan tidak dihanyutkan', karena 'kata berada dalam dasar/lubuk hati masing-masing orang'. Dan di masa depan, 'kata akan tumbuh'. Namun tumbuh yang seperti apa yang dimaksud? Dan mengapa 'kata' dikombinasikan dengan kata 'bertunas/tumbuh' yang merupakan ciri makhluh hidup? Hal ini belumlah jelas terungkap.

Baris selanjutnya adalah gareki no shita no daichi kara. 'Dari tanah di bawah puing-puing'. Gareki bermakna 'puing-puing' atau 'reruntuhan'. Kata shita berarti 'bawah', sehingga gareki no shita menunjukkan bahwa terdapat sesuatu yang letak atau posisinya berada di bawah puing atau reruntuhan. Kata daichi berarti 'bumi' atau 'tanah', sedangkan kara dalam bahasa Indonesia berpadanan dengan kata 'dari', yang menunjukkan asal muasal atau titik tolak sesuatu. Bila 'dari' dikombinasikan dengan 'tanah' maka 'tanah' menunjukkan asal muasal/titik tolak dari bertunasnya/tumbuhnya (hatsuga suru) sesuatu. Mengacu pada baris pertama bait ini, sesuatu tersebut adalah 'kata'. Dengan demikian bait gareki no shita no daichi kara bermakna '(kata akan tumbuh) dari tanah di bawah puing-puing'. Namun pusing-puing yang dimaksud pada baris ini, mengacu pada puingpuing dari benda apa? Kenapa ada puing-puing? Tetapi, bila kita mengaitkan dengan bait pertama, setidaknya terdapat kesamaan suasana imajiner yang terbangun antara kata 'puing-puing' dengan tiga kata lainnya yaitu 'hilang', 'tidak rusak', dan 'tidak dihanyutkan'. Namun apa yang menjelaskan 
keterhubungan diantara keempatnya belumlah dapat ditemukan kejelasan jawabannya.

Baris berikutnya adalah mukashi nagara no namari. 'Logat/aksen yang sejak dahulu'. Mukashi nagara adalah frase yang berarti 'sejak dahulu' atau 'tradisional', sedangkan namari bermakna 'logat' atau 'aksen'. Keduanya dihubungkan oleh partikel no, yang berfungsi untuk menghubungkan dua kata benda, yaitu mukashi nagara dan namari, sehingga baris ini bermakna logat tradisional. Dari konvensi kebahasaan, muncul persoalan pada baris ini, yaitu pada koherensinya dengan baris-baris sebelumnya, dengan kata lain, baris ini tampak tidak berhubungan dengan baris sebelumnya. Apa maksud dari ungkapan 'aksen/logat tradisional' yang tiba-tiba muncul tanpa ada identifikasi yang jelas mengenai kesamaan di antara baris ini dengan baris-baris sebelumnya? Selain itu tidak ada hal yang dapat memandu ke arah substansi atau unsur yang disamakan, sehingga dengan dasar konvensi bahasa, puisi ini telah mulai memperlihatkan heterogenitas dan keterpecahan makna. Apa yang membuat 'aksen/logat tradisional' memiliki hubungan dengan 'kata yang akan tumbuh dari tanah di bawah puing-puing'? Belum terlihat secara jelas jawaban atas pertanyaan ini.

Permasalahan yang sama juga berlaku pada baris kempat dan kelima yang juga tampak lepas dari dua baris pertama. Baris keempat, yaitu hashirigaki no moji. 'Tulisan/huruf yang ditulis dengan tergesagesa'. Hashirigaki terdiri dua karakter kanji yaitu hashiri dan gaki. Hashiri berasal dari kata hashiru yang bermakna 'berlari', sedangkan kaki berasal dari kata kaku yang bermakna 'menulis', sehingga hashirigaki berarti 'menulis dengan tergesa-gesa', dan moji bermakna 'tulisan' atau 'huruf'. Dengan demikian, baris hashirigaki no moji bermakna 'tulisan/huruf yang ditulis dengan tergesa-gesa'. Baris kelima yaitu togiregachina imi. 'Makna yang cenderung terputus'. Togire berarti 'terputus' atau 'putus', gachi merupakan ungkapan yang menunjukkan kecenderungan atau sering (frekwentatif). Gachi melekat pada kata togire, sehingga togiregachi berarti 'cenderung terputus'. Kata imi artinya 'makna' atau 'arti'. Kata togiregachi menjelaskan kata imi sehingga berarti 'makna yang cenderung terputus'. Dua baris ini memunculkan persoalan yang serupa dengan yang sebelumnya, yaitu munculnya pertanyaan mengenai apa yang membuat 'tulisan/huruf yang ditulis dengan tergesagesa' dan 'makna yang cenderung terputus' memiliki hubungan dengan 'logat/aksen tradisional'? Bersama dengan dengan baris ketiga, baris keempat dan kelima di bait ini seolah-olah terlepas dari baris-baris sebelumnya. Tidak ada identifikasi yang dapat memberikan kesan kesinambungan antara ketiga baris ini dengan baris-sebelumnya. Karena itu, sampai pada dua baris ini, kembali terlihat heterogenitas dan keterpecahan makna pada puisi ini. Namun demikian, meskipun secara samar, ketiga baris ini satu sama lain seolah-olah memiliki pertalian dengan suatu hal, meski entah apa. Hingga baris ini, jawaban atas pertalian tersebut belum dapat terjelas secara pasti.

Bait 3.

言い古された言葉が

(Iifurusareta kotoba ga)

苦しみゆえに廹生る

(Kurushimi yueni yomigaeru)

哀しいゆえに深まる

(Kanashii yueni fukamaru)

新たな意味へと

(Aratana imi e to)

沈黙に裹打ちされて

(Chinmokuni urauchi sarete)

Baris pertama dari bait ketiga adalah iifurusareta kotoba ga. 'Meskipun bahasa klise'. Iifurusareta kotoba dalam bahasa Indonesia berpadanan dengan kata 'bahasa klise'. Klise dalam Kamus Besar Bahasa Indonesia bermakna gagasan (ungkapan) yg terlalu sering dipakai; tiruan; hasil meniru. 'Bahasa klise' dianggap sebagai topik karena ditandai dengan kemunculan partikel $g a$ setelahnya yang berfungsi sebagai penanda topik/subyek pada kalimat. Namun muncul persoalan pada baris ini, yaitu masalah koherensinya dengan bait-bait sebelumnya. Baris ini seolah-olah muncul secara terpisah tanpa ada hubungannya dengan bait-bait sebelumnya. Topik yang hendak dijelaskan pun terputus pada baris ini. Mengapa dimunculkan 'bahasa klise' pada bait ini? Bahasa klise yang mana yang dimaksud? Lalu ada apa dengan bahasa klise? Tidak ada pemecahan yang jelas atas pertanyaan ini. Hanya kesamaan pada adanya kata 'kotoba' pada 'iifurusareta kotoba' yang mungkin menghubungkan baris ini dengan baris-baris 
sebelumnya, meski tidak jelas pula apa keterhubungannya.

Baris kedua yaitu kurushimi yueni yomigaeru. 'Karena penderitaan, hidup kembali'. Kurushimi bermakna 'penderitaan'; 'kesusahan'; 'kemelaratan'; 'kesengsaraan'. Empat kata yang mewakili situasi yang amat sulit yang dihadapi oleh seorang manusia, yang pada umumnya akan berujung pada keterpurukan hidup. Namun pada baris ini, penderitaan justru memunculkan semangat baru berupa ungkapan yomigaeru yang bermakna 'hidup kembali'. Sifat paradoks yang seperti ini ditandai oleh penggunaan yue ni yang bermakna 'sebab itu'; 'karena itu'. Namun muncul pertanyaan mengenai baris ini, apa yang hidup kembali? Bila kita kembali pada baris sebelumnya, tampaknya baris ini merupakan penjelasan untuk baris pertama di bait ini, yaitu tentang 'bahasa klise'. Dengan demikian baris kurushimi yue ni yomigaeru berarti '(justru) karena penderitaan, (bahasa klise) hidup kembali',

Baris berikutnya adalah kanashii yueni fukamaru. 'Karena sedih, mendalam'. Kanashii berarti 'sedih', sedangkan yueni berarti 'sebab itu'; 'karena itu'. Kata fukamaru berarti 'mendalam'. Sama seperti baris kedua, baris ketiga ini juga tampaknya merupakan baris yang koheren dengan baris pertama. Dengan kata lain, baris ini memuat penjelasan tentang topik 'bahasa klise'. Dengan demikian baris ini bermakna '(justru) karena sedih, (bahasa klise menjadi) mendalam'.

Baris keempat yaitu arata na imi e to. 'Menjadi makna yang baru'. Arata na merupakan kata sifat jenis na yang berarti 'baru'. Ciri dari kata sifat jenis ini adalah apabila ia dikombinasikan dengan kata benda, maka na perlu dilekatkan pada kata sifat jenis ini. Misalnya yang terdapat pada baris ini, yaitu arata na imi. Imi artinya adalah 'makna' atau 'arti', sehingga arti arata na imi adalah 'makna yang baru'. Terdapat partikel $e$ dan to di akhir baris ini. $E$ adalah partikel yang menunjukkan tujuan atau sasaran. Sedangkan partikel to memiliki beberapa fungsi, namun dalam kombinasinya dengan partikel $e$ menjadi $e$ to, partikel to cenderung berfungsi untuk mengungkapkan adanya perubahan yang terjadi. Umumnya partikel to dikombinasikan dengan kata naru menjadi to naru, yang maknanya adalah 'menjadi $\sim$. Namun bila naru dilesapkan pun, partikel ini teridentifikasi sebagai fungsi tersebut. Dengan demikian, arti dari baris aratana imi e to adalah 'menjadi makna yang baru'. Apa menjadi makna yang baru? Apabila dikaitkan dengan baris kedua dan ketiga, tampaknya baris ini masih bertutur tentang topik 'bahasa klise' di baris pertama.

Baris terakhir dari puisi ini adalah chinmoku ni urauchi sarete. 'Ditopang oleh kebisuan'. Chinmoku artinya 'keheningan' atau 'kebisuan', yaitu suasana atau kondisi lengang atau sepi tanpa ada kegaduhan bahkan tanpa ada bunyi atau suara apapun, atau kondisi diamnya manusia tanpa bisa berkata-kata apapun. Partikel $n i$ yang terdapat pada baris ini berkaitan erat dengan penggunaan bentuk pasif pada kata urauchi sarete yang berasal dari kata urauchi suru yang bermakna 'menopang' atau 'mendukung', sehingga urauchi sarete bermakna 'ditopang' atau 'didukung'. Dalam kalimat yang memuat kata kerja bentuk pasif, partikel $n i$ berfungsi sebagai penanda pelaku dari terjadinya sesuatu yang dalam bahasa Indonesia padanannya adalah 'oleh', sehingga pada baris chinmoku ni urauchi sarete bermakna 'ditopang oleh kebisuan/keheningan'. Bentuk te pada kata urauchi sarete di akhir baris ini menunjukkan secara tidak langsung bahwa sebenarnya masih ada hal atau penjelasan lain yang ingin ditambahkan, namun karena lawan bicara dianggap dapat cukup mengerti kelanjutannya, maka kalimatnya dipenggal begitu saja dan dianggap sebagai akhir kalimat. Jika mengacu pada baris-baris sebelumnya yang memaparkan tentang topik 'bahasa klise', khususnya dari baris keempat, maka kemungkinan maksud dari baris terakhir ini secara menyeluruh adalah bahwa (salah satu) faktor yang mendorong bahasa klise berubah maknanya menjadi baru adalah karena didukung/ditopang oleh kebisuan. Namun apa maksud dari kebisuan pada baris ini? Serta kebisuan atau keheningan yang seperti apa? Kebisuan atau keheningan dari siapa atau apa? Tidak ada jawaban yang jelas dari pertanyaan-pertanyaan ini.

Kesan heterogenitas dan keterpecahan makna terlihat pada beberapa bagian dalam puisi ini. Hal ini ditandai dengan munculnya banyak pertanyaan yang mengarah pada apa kesinambungan yang ada di antara baris yang satu dengan baris yang lainnya. Meskipun terdapat identifikasi pada beberapa hal yang mungkin dapat dijadikan sebagai dasar asumsi dari keterhubungan di antaranya baris-baris tersebut, 
namun secara umum masih bersifat samar dan tidak jelas.

\section{Pembacaan Hermeneutik}

Pembacaan hermeneutik adalah pembacaan yang bermuara pada ditemukannya satuan makna puisi. Karena puisi dipahami sebagai sebuah satuan yang bersifat struktural, pembacaan hermeneutik ini pun dilakukan secara struktural, yaitu bergerak bolakbalik dari bagian ke keseluruhan dan kembali ke bagian dan seterusnya. Hasil yang diperoleh dari pembacaan atas kalimat pertama, baris pertama puisi di atas, misalnya, dapat direvisi dan diulas kembali setelah proses pembacaan berlangsung ke bagian berikutnya dan dengan masukan dari hasil pembacaan atas bagian yang kemudian tersebut. Karena puisi dipahami sebagai satuan yang menyerupai sebuah donat, yang mengandung ruang kosong di tengahnya, ruang kosong yang dapat menjadi matriks dari puisi tersebut, pembacaan hermeneutik inipun dilakukan dengan mempertimbangkan unsur-unsur yang tidak tampak secara tekstual, unsur-unsur gramatik yang dapat bersifat potensial seperti presuposisi yang terkandung dalam bahasa dan dapat pula bersifat aktual yang berupa teks-teks yang ada sebelumnya, baik yang berupa mitos, karya sastra lain, dan sebagainya.

\section{Hipogram potensial}

Yang dimasukkan ke dalam hipogram potensial ini adalah segala bentuk implikasi dari makna kebahasaan, baik yang berupa presuposisi, maknamakna konotatif yang sudah dianggap umum, dan sebagainya. Implikasi itu tidak dapat ditemukan di dalam kamus misalnya, akan tetapi sebenarnya telah ada dalam pikiran penutur bahasa pada umumnya.

\section{Bait 1}

何もかも失って

(Nanimo kamo ushinatte)

言葉まで失ったが

(Kotoba made ushinatta ga)

言葉は壊れなかった

(Kotoba wa kowarenakatta)

流されなかった

(Nagasarenakatta)

ひとりひとりの心の底で

(Hitorihitori no kokoro no soko de)
Pada baris pertama bait pertama yang berbunyi 'nanimokamo ushinatte' yang bermakna 'segalanya hilang' mengimplikasikan bahwa pada masa sebelumnya 'segalanya ada' dan kemudian menjadi 'lenyap'. Baris ini mengungkapkan kegelisahan batin yang disampaikan oleh seseorang mengenai hilangnya segalanya, yang terjadi sebagai akibat dari sesuatu yang belum jelas. Baris kedua yaitu 'kotoba made ushinatta ga' yang bermakna 'hingga kata (pun) lenyap' masih bertalian dengan baris sebelumnya. Baris ini mengimplikasikan intensitas kehilangan hingga pada hal yang tidak umum terjadi yaitu hilangnya 'kata'. 'Hilangnya kata-kata' mengacu pada konotasi keterpanaan dan keterkejutan yang dialami oleh seseorang akibat dari sesuatu. Baris ini menunjukkan penggambaran intensitas 'kehilangan' yang tinggi yang mengakibatkan munculnya perasaan keterkejutan atau shock sehingga lisan tak dapat lagi berkata-kata. Baris ini memiliki pertalian dengan dua baris yang muncul berikutnya yaitu kotoba wa kowarenakatta '(namun) kata tidak rusak' dan nagasarenakatta 'tidak hanyut'. Baris 'tidak rusak' dan 'tidak hanyut' yang mengacu pada 'kata', mengimplikasikan adanya keadaan 'rusak' dan 'hanyut' yang menimpa 'segalanya yang hilang' di daerah tersebut. Dengan demikian, faktor penyebab atas keterkejutan atau shock yang dialami seseorang tersebut menjadi cukup jelas, yaitu karena keadaan rusak serta hanyut yang terjadi pada segalanya yang telah hilang dari orang tersebut. Keadaan 'rusak' memunculkan penggambaran sebuah kekuatan yang dahsyat yang mampu meremukkan segala hal yang ada, sedangkan keadaan 'hanyut' memunculkan penggambaran kondisi yang terjadi akibat suatu arus yang mengalir secara deras. Hal ini menimbulkan implikasi lanjutan yang memperjelas baris pertama, bahwa keadaan 'segalanya hilang' disebabkan oleh suatu bencana yang terjadi yang disimpulkan dari keadaaan 'rusak' dan 'hanyut'. Sehingga makna dari tiga baris ini adalah meskipun 'kata' telah hilang/lenyap, namun tidak seperti halnya segalanya yang rusak dan hanyut akibat bencana, 'kata' tidaklah rusak dan tidak hanyut terbawa arus. Baris berikutnya yaitu hitorihitori no kokoro no soko de, '(kata tetap melekat) di dasar hati tiap-tiap orang'. Baris ini masih berkaitan dengan 'kata' yang menjadi topik pada baris sebelumnya. Dengan adanya kata 'tiaptiap orang' pada baris ini, memberikan kesan bahwa bukan hanya 'seorang' saja yang merasakan 
keterkejutan atas peristiwa kehilangan segalanya, melainkan 'banyak orang'. Sampai pada bait ini, puisi ini telah memberikan empat pasangan oposisional yaitu 'hilang/lenyap' dengan 'ada', 'rusak dengan 'tidak rusak', 'hanyut' dengan 'tidak hanyut', dan 'seorang' dengan 'banyak orang'.

Bait 2

言葉は発芽する

(Kotoba wa hatsuga suru)

瓦礫の下の大地力ら

(Gareki no shita no daichi kara)

昔ながらの訛り

(Mukashi nagara no namari)

走り書きの文字

(Hashirigaki no moji)

途切れがちな意味

(Togiregachina imi)

Baris pertama yaitu kotoba wa hatsuga suru. 'Kata akan tumbuh'. Baris ini menggunakan majas personifikasi, yaitu menganalogikan 'kata', yang merupakan sesuatu yang bersifat abstrak, sebagai makhluk hidup yang dapat mengalami pertumbuhan. Kata 'tumbuh' yang disandingkan dengan 'kata' menimbulkan interpretasi bahwa 'kata' mengalami sebuah perkembangan dari awalnya yang bersifat statis dan hanya memiliki cakupan makna tertentu saja, kemudian menjadi hidup, bersifat dinamis, dan bertambah bobot maknanya dari sebelumnya. Kemunculan baris pertama ini bertalian dengan baris terakhir di bait pertama yang menjelaskan tentang terpendamnya kata-kata dalam lubuk hati tiap orang. Kondisi 'terpendam' lekat dengan kesan 'statis' dan hal inilah yang mendasari koherensi yang terjadi di antara akhir bait pertama dengan awal bait kedua. Selain itu, kata 'akan tumbuh' mengimplikasikan bahwa di masa kini 'kata belum tumbuh' dan masih dalam keadaan terpendam atau tertutup, sehingga mengimplikasikan adanya pergeseran masa dari masa kini menuju masa depan. Masa kini diwakili oleh keadaan 'terpendamnya kata', sedangkan masa depan diwakili oleh keadaan 'akan tumbuh'. Hal ini memunculkan pasangan oposisional yang baru, yaitu 'masa kini' dengan 'masa depan'.

Baris selanjutnya yaitu gareki no shita no daichi kara. Dari (dalam) tanah di bawah puing-puing. Baris kedua ini menjelaskan letak tumbuhnya 'kata' yang dinyatakan pada baris sebelumnya. Sehingga pertalian antara dua baris ini terjelaskan menjadi 'kata' akan tumbuh dari dalam tanah di bawah puingpuing reruntuhan pasca bencana. Ungkapan 'puingpuing' lekat dengan konotasi kekacauan atau kehancuran yang mengggambarkan keadaan yang porak poranda. Dari dua baris pertama ini, tergambar bahwasanya suatu saat 'kata' akan mengalami perkembangan sebagai akibat dari kekacauan yang terjadi.

Tiga baris terakhir pada bait kedua yaitu mukashi nagara no namari, hashirigaki no moji, dan togiregachina imi yang secara pembacaan heuristik berarti 'aksen/logat tradisional', 'huruf/tulisan yang ditulis tergesa-gesa', dan 'makna yang cenderung terputus'. Tiga baris ini kemungkinan berkaitan dengan 'puing-puing' yang berkonotasi dengan kekacauan yang terdapat pada baris kedua. Dengan demikian, implikasi tiga baris ini mengarah pada kekacauan yang terjadi pada tataran penggunaan 'kata' yang mungkin terjadi pada pada realitas kehidupan manusia. Ada yang terwarnai oleh aksen/logat tradisional/daerah, ada yang berupa tulisan yang ditulis secara terburu-buru, dan ada pula yang maknanya cenderung terputus. Ketiga hal ini mewakili kondisi 'puing-puing kata' yang menggambar ketidaksempurnaan/kekacauan dalam perlakuan manusia terhadap kata-kata dalam kesehariannya. Ketidaksempurnaan yang sejajar dengan gambaran 'puing-puing' yang terserak karena bencana.

Bait 3.

言い古された言葉が

(Iifurusareta kotoba ga)

苦しみゆえに廹生る

(Kurushimi yue ni yomigaeru)

哀しいゆえに深まる

(Kanashii yue ni fukamaru)

新たな意味へと

(Arata na imi e to)

沈黙に裹打ちされて

(Chinmoku ni urauchi sareta)

Bait ini diawali dengan baris iifurusareta kotoba ga. Iifurusareta kotoba bermakna 'bahasa klise', yang menggambarkan tentang kata-kata yang sering kita gunakan sejak lama. Hal ini menimbulkan implikasi 
pada timbulnya perasaan sangat terbiasa (familiar) dan kehilangan esensi dari kata-kata tersebut. Baris ini dilanjutkan dengan dua baris berikutnya yaitu kurushimi yueni yomigaeru, 'karena penderitaan, hidup kembali' dan baris kanashii yueni fukamaru, 'karena sedih, (semakin) mendalam'. Dua baris ini selain memperjelas baris pertama tentang 'bahasa klise', juga memberikan kejelasan pada kondisi perihal tumbuh dan berkembangnya 'kata' yang terdapat pada awal bait kedua. 'Karena penderitaan, hidup kembali' mengimplikasikan bahwa sebelum penderitaan itu terjadi, 'bahasa klise' telah kehilangan 'ruh'nya dan memiliki kesan mengalami kondisi statis karena seringnya digunakan dalam kehidupan sehari-hari. Kemudian karena penderitaan yang terjadi, 'bahasa klise' ini menjadi hidup kembali (yomigaeru) yang diinterpretasikan sebagai kedinamisan. Kemudian baris 'karena sedih, (semakin) mendalam' mengimplikasikan bahwa 'bahasa klise' sebelumnya cenderung bermakna dangkal. Melalui kesedihan, ditemukan adanya kedalaman (fukamaru) makna yang baru dari 'bahasa klise'. Terjadi perubahan kesan dari makna 'bahasa klise" yang awalnya terasa biasa, menjadi kata yang lebih bermakna dan berbobot, bahkan berubah menjadi makna yang baru. Hal ini tergambar pada baris keempat yaitu arata na imi e to. Baris ini mengimplikasikan adanya makna yang lama dari 'kata', sebelum ia berubah menjadi makna yang baru. Karenanya, sampai pada baris ini, ditemukan pasangan oposisional yang berikutnya yaitu 'makna baru' dengan 'makna lama'.

Baris terakhir puisi ini yaitu chinmoku ni urauchi sareta, 'telah ditopang oleh kebisuan'. Baris terakhir ini berhubungan dengan baris sebelumnya yang memberikan penjelasan tentang perubahan makna lama pada 'bahasa klise' kepada maknanya yang baru. Perihal 'bahasa klise' yang hidup kembali, semakin mendalamnya makna, serta perubahannya menjadi makna yang baru, selain karena penderitaan dan kesedihan, namun juga karena situasi keheningan (chinmoku) yang menopangnya menjadi demikian. Kebisuan dan keheningan ini berkaitan dengan bait pertama baris kedua dan baris kelima yaitu kotoba made ushinatta ga dan hitorihitori no kokoro no soko de yang menggambarkan hilang serta lenyapnya katakata yang terucap dari bibir manusia dan tersimpan dalam batin tiap-tiap orang, karena penderitaan dan kesedihan yang dirasakan. Kebisuan serta keheningan inilah yang mendukung terciptanya makna yang baru dari bahasa klise.

\section{Matriks, Model, dan Hipogram Aktual}

Dengan hipogram-hipogram potensial di atas, pembacaan hermeneutik ini telah berhasil mendapatkan kesatuan dunia imajiner puisi yang dalam pembacaan terdahulu (heuristik) terkesan beraneka ragam dan terpecah. Gambaran yang didapat adalah berupa gambaran batin yang dicurahkan seseorang yang merasa terkejut atas peristiwa kehilangan yang terjadi pada segalanya yang ia miliki, hingga hilang pula kata-kata yang dapat terucap dari mulut. Namun ia hidup pada sebuah keyakinan bahwa di masa depan, kata akan tumbuh (masa kini dan masa depan). Meski terpendam dalam batin manusia, kata akan tumbuh dari balik puing-puing kehancuran (batiniah dan lahiriah, tertutup dan terbuka). Puing-puing kehancuran yang terwujud dalam aksen/logat tradisional yang kita ucapkan, dalam ketergesaan tulisan yang kita lakukan, dan dalam makna yang cenderung terputus yang kita hasilkan. Kekacauan dari keadaan yang sama seperti yang tercermin melalui puing-puing yang terserak karena bencana. Pada bait ketiga didapatkan gambaran mengenai penggunaan kata sebagai bagian yang tak terpisahkan dari hidup manusia. Karena terlalu sering mengalami pengulangan dalam keseharian hidup manusia (bahasa klise), kata menjadi hilang esensi dan menjadi dangkal makna. Namun dengan penderitaan dan kesedihan, kata yang sebelumnya menjadi hilang esensi, kemudian hidup kembali, dan kata yang sebelumnya menjadi dangkal menjadi semakin dalam maknanya.

Namun bangunan imajiner di atas belum sepenuhnya utuh, membentuk satu satuan makna yang menjadi pusatnya, yang di dalam semiotika Riffaterre ini sebagai matriks. Matriks ini dapat berupa satu kata atau satu kalimat yang tidak selalu teraktualisasi di dalam lirik yang bersangkutan. Yang jelas ia merupakan sumber dari seluruh makna yang ada dalam setiap kata dan kalimat yang ada di dalamnya. Matriks ini, misalnya, yang mempersatukan berbagai pasangan oposisional yang tersebar dalam keseluruhan lirik, yang menjadi "roh" dalam berbagai hubungan ekuivalensi antarnya. 
Tetapi sebelum dilakukan identifikasi terhadap matriks itu, ada baiknya diidentifikasi modelnya terlebih dahulu. Model adalah aktualisasi pertama dari matriks, aktualisasi yang dapat berupa satu kata atau kalimat tertentu. Yang khas, yang membuat model berbeda dari kata-kata atau kalimat lain yang ada dalam puisi yang bersangkutan adalah sifat puitisnya, eksistensinya sebagai tanda puitis. Dan, sebuah tanda dikatakan puitis hanya bila tanda itu bersifat hipogramatik dan karenanya monumental.

Ada tiga tanda yang tampaknya monumental dalam puisi ini, yaitu kotoba made ushinattaga, kotoba ga hatsuga suru, dan aratana imi e to. 'Kata' telah menghilang secara lahiriah, namun secara batiniah 'kata' akan tumbuh membentuk makna yang baru. Dengan pemahaman yang demikian tampak bahwa delapan pasangan oposisional yang ditemukan dalam puisi ini, yaitu 'ada' dengan 'tiada', 'rusak' dengan 'tidak rusak', 'hanyut' dengan 'tidak hanyut', 'seorang' dengan 'banyak orang', 'masa kini' dengan 'masa depan', 'statis' dengan 'dinamis', 'dangkal' dengan 'dalam', dan 'makna lama' dan 'makna baru', kedelapannya berasal dari satu matriks yang sama yaitu 'ikatan'. 'Ikatan'lah yang membingkai kedelapannya, karena ikatan dapat terjalin (ada, tidak rusak, tidak hanyut, masa kini) dan putus (tiada/lenyap, rusak, hanyut, masa depan), ikatan merupakan hubungan antara sejumlah orang (seorang-banyak orang), ikatan mengalami pasang surut (statis-dinamis, dangkal-dalam, makna lamabaru).

Dalam konteks terciptanya puisi ini, jelas bahwa terdapat kaitan yang sangat mendalam antara puisi ini dengan bencana gempa bumi dan tsunami yang terjadi di Jepang tahun 2011. Pembangunan wacana mengenai hikmah di balik terjadi suatu musibah, berupa terbarukannya kembali esensi ikatan (bond) yang terjadi di dalam masyarakat Jepang pasca terjadinya bencana tersebut, yang terwujud melalui tumbuhnya kesadaran kolektif serta kesadaran akan pentingnya merajut tali persatuan dan solidaritas sosial. Hal ini juga berkaitan dengan kemunculan sebuah istilah, yaitu kizuna (絆) yang berarti ikatan (bond), yang menjadi popular setelah karakter kanji ini terpilih menjadi Kanji of the Year pada tahun 2011 di Jepang dan menjadi istilah yang umum ketika perbincangan seputar bencana gempa bumi.
Dengan terjadinya bencana, masyarakat Jepang menjadi tersadarkan pada sesuatu yang sebenarnya telah ada pada diri mereka sejak lama. Bencana ini telah memberi pengaruh yang besar pada pandangan masyarakat Jepang. Saat bencana terjadi, ketika mereka mengkhawatirkan keberadaan teman-teman dan kerabatnya, mereka sekali lagi mulai memahami pentingnya hubungan antara satu sama lain. Banyak yang merasakan pentingnya hubungan antar manusia. Benar bahwasanya bencana meninggalkan puingpuing kehancuran pada hidup banyak orang, namun juga benar bahwa bencana itu terjadi sebagai sebuah pengingatan akan berapa banyak dari kita yang telah lupa bahwa ikatan yang kita jalin membantu kita untuk dapat melihat lebih jauh mengenai diri kita sendiri.

\section{KESIMPULAN dan SARAN}

Berdasarkan hasil analisis pada bab empat, diperoleh kesimpulan bahwa tanda yang ada dalam puisi Kotoba karya Tanikawa Shuntaro memusat pada sebuah makna yaitu 'ikatan', yang di dalamnya terbingkai delapan pasangan oposisional, yaitu 'ada' dengan 'tiada', 'rusak' dengan 'tidak rusak', 'hanyut' dengan 'tidak hanyut', 'seorang' dengan 'banyak orang', 'masa kini' dengan 'masa depan', 'statis' dengan 'dinamis', 'dangkal' dengan 'dalam', dan 'makna lama' dan 'makna baru'.

Kotoba yang bermakna 'kata' yang terdapat dalam puisi ini merupakan representasi dari ikatan (bond). Dengan 'kata', manusia menciptakan hubungan satu sama lain. 'Kata yang hilang' merepresentasikan ikatan yang terputus karena hilangnya nyawa akibat bencana yang terjadi. Meski terpisahkan oleh maut, namun ikatan itu sedianya tetap ada dalam diri manusia yang ditinggalkan. 'Puing-puing kata' juga merepresentasikan mengenai kekacauan serta pasang surutnya hubungan yang terjadi dalam ikatan di antara manusia. 'Bahasa klise' merupakan perlambang dari ikatan yang sudah terjalin sejak lama, yang mengalami kejenuhan dan kehampaan karena perjalanan waktu, sehingga memudar warnanya dan merenggang ikatannya. Ikatan ini tergambar dalam jalinan ikatan pertemanan, ikatan dalam kekerabatan, ikatan dalam keluarga, dan lain-lain. Melalui peristiwa bencana yang menimbulkan penderitaan dan kesedihan, ikatan di antara manusia menjadi 
hidup kembali dan semakin mendalam. Ikatan manusia menjadi terbarukan dalam suasana hening karena duka akibat bencana.

\section{DAFTAR PUSTAKA}

[1] Halliday, M.A.K. An Introduction to Functional Grammar. London: E. Arnold, 1994.

[2] Pradopo, Rachmat Djoko. Pengkajian Puisi. Yogyakarta: Gajah Mada University Press, 2007.
[3] Selden, Raman. Panduan Pembaca Teori Sastra Masa Kini. Yogyakarta: Gajah Mada University Press, 1993.

[4] Riffaterre, Michael. Semiotics of Poetry. Bloomington and London: Indiana University Press, 1978.

[5] Jabrohim, (ed.). Metode Penelitian Sastra. Yogyakarta: Hanindita Graha Widjaya, 2003.

[6] Luke, Elmer. and David Karashima (ed.). March Was Made of Yarn: Reflections on the Japanese Earthquake, Tsunami, and Nuclear Meltdown. New York: Vintage, 2012. 